\title{
Sediment Yield Source Identification in Gilgel Gibe-I Catchment Using GIS-based RUSLE and SEDD Models for Soil Conservation Planning, South West Ethiopia
}

\author{
Gizaw Tesfaye ${ }^{1} \quad$ Degefie Tibebe ${ }^{2}$ \\ 1.Ethiopian Institute of Agricultural Research, Jima Agricultural Research Center; P.O.Box. 192 \\ 2.Ethiopian Institute of Agricultural Research, Climate, Geospatial and Biometerics Research Directorate, \\ P.O.Box 2003, Addis Ababa, Ethiopia
}

\begin{abstract}
Onsite and off-site effects of soil erosion are the biggest global environmental problems. Some of the offsite problems are silting of dams and reservoir, disruption of lake ecosystems, and increased downstream flooding. Gilgel Gibe-1 catchment has been also subjected to sedimentation and other offsite problems. This study was aimed to identify the source of sediment yield in Gilgel Gibe-1 catchment using GIS-based RUSLE and SEDD models for soil conservation planning. Primary and secondary data from different sources were used to estimate soil loss from the catchment using GIS-based RUSLE model. Rainfall-runoff erosivity, soil erodibility, topographic effect, surface coverage, and land management practice of the catchment were used as an input to RUSLE model. Sediment Delivery Ratio was estimated using the SEDD model. The result of this study shows the mean annual soil loss of the catchment is $62.98 \mathrm{t} \mathrm{ha}^{-1} \mathrm{year}^{-1}$ which are about $26.56 \times 106 \mathrm{t}^{-1} \mathrm{rr}^{-1}$ and the mean sediment delivery ratio is 0.1367 . The mean annual sediment yield of the catchment is $8.61 \mathrm{t} \mathrm{ha}^{-1} \mathrm{year}^{-1}$ and the overall catchment area contributes about $3.63 \times 106 \mathrm{t} \mathrm{year}^{-1}$ sediment to the reservoir at the dam site. On the bases of mean annual sediment yield, a source of sediment yield areas are identified and prioritized. Accordingly, SW4, SW5, SW3, SW6, SW7, SW8, SW9, SW2, and SW1 got priority level in the order of 1 to 9. Sediment yield $>10 \mathrm{t}$ ha $^{-1}$ year $^{-1}$ covers $15.75 \%$ of the catchment area and $0-5 \mathrm{t} \mathrm{ha}^{-1}$ year ${ }^{-1}$ covers $78.22 \%$, of the catchment. The result of this study indicates the catchment and reservoir are under the problem of soil loss and siltation, respectively. Therefore, it is recommended that immediate action, soil, and water conservation measures, should be taken in the catchment according to the priority of sub-watersheds and further detail study is suggested with the support of experimental test plots.
\end{abstract}

Keywords: GIS, RUSLE, SEDD, Sediment Yield, Soil Loss, Sub-watershed.

DOI: $10.7176 / \mathrm{JEES} / 9-2-04$

\section{INTRODUCTION}

Soil erosion is one of the biggest global environmental problems resulting in both on-site, (loss of topsoil, minimize water holding capacity of the soil, pollutants carried off by water), and off-site effects (silting of dams, disruption of lake ecosystems, contamination of drinking water and increased downstream flooding) (Niu et al., 2003). Sediment yield refers to the part of the eroded material, normally originating from soil erosion processes, which is conveyed to the outlet of the watershed.

Soil erosion is a serious problem in the Ethiopian highland areas that increased sedimentation of reservoirs and lakes (Bezuayehu, 2006). The Koka reservoir, supplied by the Awash and the Modjo rivers, was formed by the construction of the Koka dam in 1959 (with an original storage capacity of $1650 \mathrm{Mm}^{3}$ ) for developing hydroelectric power for domestic use (Musa et al., 2005). In 2000, Addis Ababa suffered power shortages, even during the rainy season, after turbines at the Koka Dam became clogged with sediment (Hathaway, 2008). The mean annual sedimentation rate of this reservoir has been estimated or cited by several authors: $2302 \mathrm{t} \mathrm{km}^{-2}$ year- $^{-}$ ${ }^{1}$ (Devi et al., 2008); 13-20 $\mathrm{Mm}^{3}$ year $^{-1}$ (Musa et al., 2005). It is estimated that the transboundary rivers that originate from the Ethiopian highlands carry about 1.3 billion tons/year of sediment to neighboring countries whereas the Blue Nile alone carries 131 million tons/year (Kidane and Alemu, 2015).

The high rate of soil erosion/ sedimentation threats the lifespan of Gilgel Gibe-1 hydropower reservoir which also affect Gilgel Gibe-2 which uses the water released from Gilgel Gibe-1 (Adugna et al., 2013). Previous study done by Devi et al. (2008) indicates that there was a rapid loss of storage volume due to excessive soil erosion and subsequent sedimentation in Gilgel Gibe-1 dam reservoir. Further their study shows that Gilgel Gibe-1 hydroelectric dam had a capacity of $917 \mathrm{Mm}^{3}$ water and the reservoir capacity had been reduced further by annual sediment loads of $4.50 \times 10^{7} \mathrm{t}_{\text {year }}^{-1}$ which could occupy about $3.75 \times 10^{7} \mathrm{~m}^{3}$ year-1. Based on the results of physicochemical parameters and data obtained using the observational checklists, it is estimated that Gilgel Gibe I dam's volume will be reduced by half within 12 years and would be completely filled with sediments within 24 years unless timely remedial measures are taken.

Deforestation, land degradation due to poor land management practices associated with the rugged topography and the erosive rainfall in the basin pose a major threat to the lifespan of Gilgel Gibe 1 hydropower 
(Nebiyu,2010). Explanatory assessment of sediment sources has been conducted and landslides, river bank erosion and gullies were found to be the major sediment sources in Gilgel Gibe-I catchment. This assessment revealed that more than 200 hectares of severe landslide areas were connected to the major rivers, with more than 651 major gullies contributing a washed soil volume of about 12.3 million $\mathrm{m}^{3}$ (Negash and Mesfin, 2011).

Sediment load due to soil loss is the major problem for Gilgel Gibe-I reservoir (Devi et al., 2008; Negash and Mesfin, 2011; Dawud et al., 2014; Adeba, 2016; Adugna et al., 2013). These studies in the study area recommended that appropriate mitigations should be done to overcome the problem and increase the lifespan of the dam. However, these studies didn't identify hotspot areas that contribute a large amount of sediment load to the reservoir which is very important to mitigate the problem. In addition to this, varying results were reported by different researchers on the amount of soil loss and sediment load. Taking into account these gaps, this paper tried to identify areas of high sediment yield sources by prioritizing the catchment on the bases of sub watershed which ultimately used for soil and water conservation planning in Gilgel Gibe-1 catchment. In addition, it adds a drop of information on the amount of soil loss and sediment load apart from reported by different studies so far.

Many accurate soil erosion models were developed over the last four decades to assess soil erosion risk at different levels of a single slope, catchment, regional and global scales (Prasannakumar V., et al, 2012). the most widely-used model for erosion assessment and conservation planning is still the empirically-based Universal Soil Loss Equation (USLE) and its direct offshoots, the Revised USLE (RUSLE) and Modified USLE (MUSLE). The combined use of Geographical Information Systems (GIS), RUSLE and SEDD has been realized to be an effective method for estimating water erosion and sediment yield (Fernandez et al.2003). This is due to their consideration of spatial distribution, applicability to watersheds and the inputs needed for the model is simple and flexible(Ferro and Porto, 2000).

\section{MATERIALS AND METHODS}

\subsection{Description of the study area}

Gilgel Gibe-1 catchment is located in South West part of Ethiopia in Jimma zone of Oromia Regional State in Omo-Gibe basin with a total area of $4218 \mathrm{~km}^{2}$ at the dam site(outlet) and it is located in between $7^{\circ} 19^{\prime} 7.15^{\prime \prime}$ and $8^{\circ} 12^{\prime} 9.49^{\prime \prime} \mathrm{N}$ latitudes and $36^{\circ} 31^{\prime} 42.60^{\prime \prime}$ to $37^{\circ} 25^{\prime} 16.05^{\prime \prime} \mathrm{E}$ longitudes.

The catchment is generally characterized by rouge topography with deep V-shaped valleys in the flanks and flat terraces around the Gibe river in the center of the catchment with an average elevation of about $1700 \mathrm{~m}$ above mean sea level (Demissie, et al., 2013).

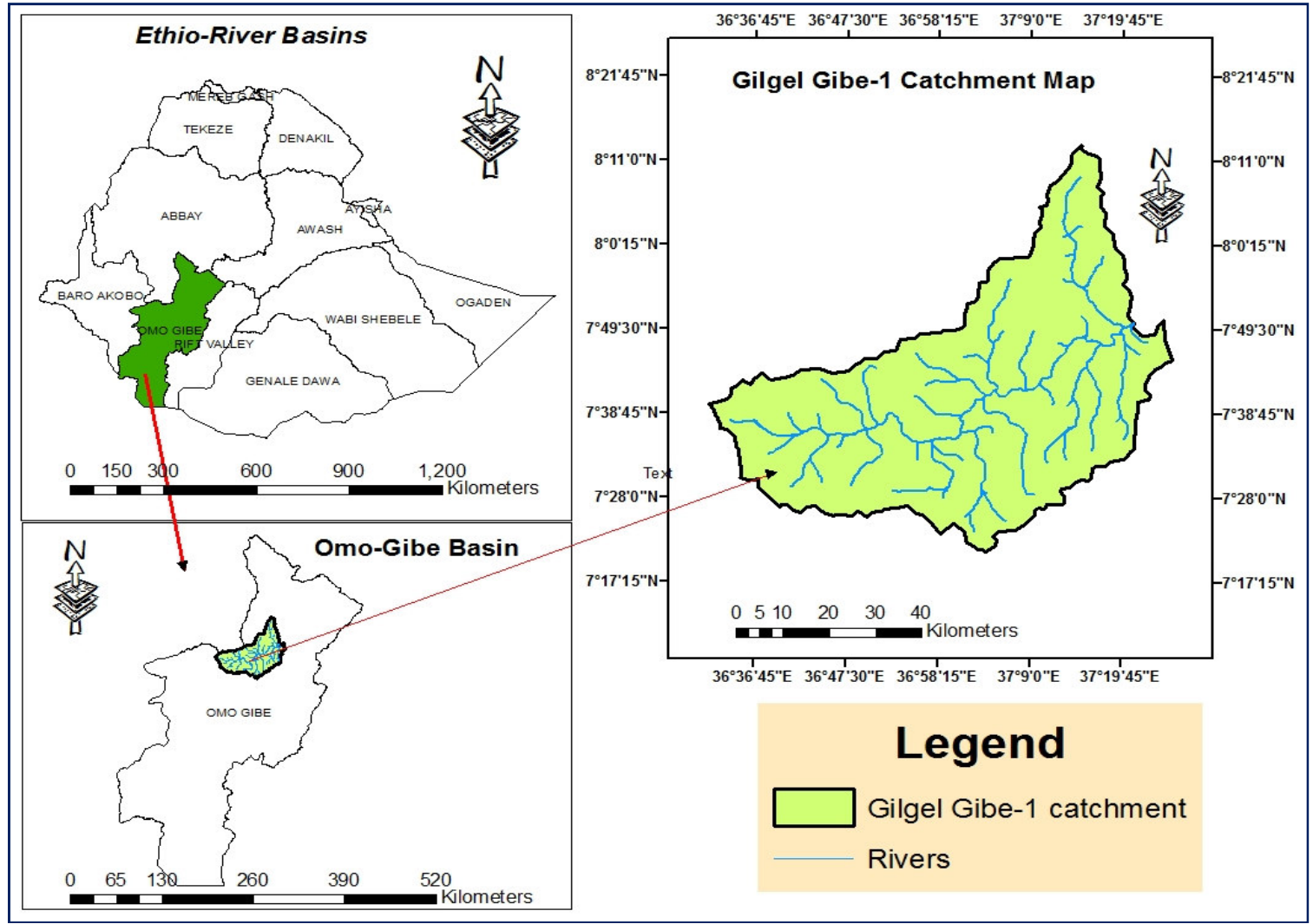

Figure 1.Location map of the study area.

The geology of the catchment is related to the uplifting of the East African rift valley in the Upper Eocene 
(Tadesse et al., 2003). The major soil types in the study area are Nitisols, Fluvisols, Acrisols, and Vertisols, with Nitisol domination (FAO-UNESCO, 1974). The catchment is largely comprised of cultivated land and grazing land. In the upper part of the catchment coffee based forest is practiced. Generally, a mixed farming system is common in the study area (Broothaerts et al.., 2012).

The seasonal rainfall distribution takes a uni-modal pattern and it is maximum during the summer and minimum during the winter season, influenced by the intertropical convergence zone (ITCZ) (Demissie et al., 2013). The Gilgel Gibe catchment is characterized by a wet climate with an average annual rainfall of about 1347 $\mathrm{mm}$ and an average temperature of $19^{\circ} \mathrm{C}$ with $24.78^{\circ} \mathrm{C}$ maximum temperature and $11.58^{\circ} \mathrm{C}$ minimum temperature. (Figure 2).

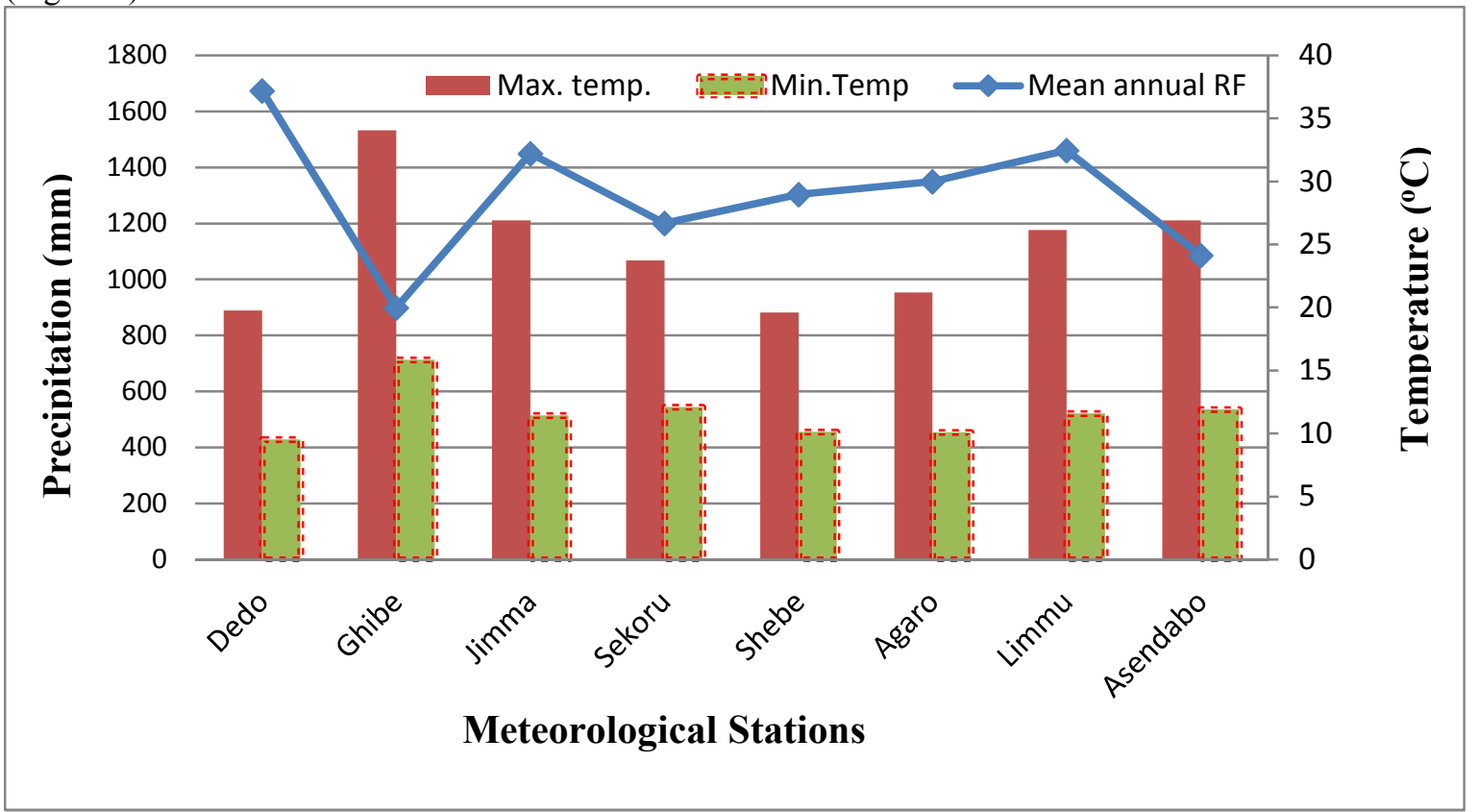

Figure 2. Mean annual rainfall, maximum and minimum temperature of stations in and nearby the catchment.

\subsection{Methods and Data Analysis}

\subsubsection{Application of RUSLE and SEDD Models for Sediment Yield Estimation}

GIS technique is integrated with two empirical soil loss models: the Revised Universal Soil Loss Equation (RUSLE); and Sediment Distribution delivery (SEDD) models. RUSLE is used to estimate mean annual soil loss (A) and SEDD is used for estimation of sediment delivery ratio (SDR).

\section{Determination of Revised Universal Soil Loss Equation (RUSLE) Model Factors}

Five major factors (rainfall pattern, soil type, topography, crop system, and management practices) are used in RUSLE for computation of average annual soil erosion expected on the field slopes and are represented in the equation given by (Renard et al., 1997):

$\mathrm{A}=$ RKLSCP

where: $\mathrm{A}=$ is the computed spatial average soil loss and temporal average soil loss per unit area (t/ha/year), $\mathrm{R}=$ the rainfall-runoff erosivity factor $(\mathrm{MJ} \mathrm{mm} /(\mathrm{ha} \mathrm{h} \mathrm{yr})), \mathrm{K}=$ the soil erodibility factor $(\mathrm{t} \mathrm{ha} \mathrm{h} /(\mathrm{ha} \mathrm{MJ} \mathrm{mm})$ ), $\mathrm{L}=$ the slope-length factor, $\mathrm{S}=$ the slope steepness factor, $\mathrm{C}=$ the cover management factor and $\mathrm{P}=$ the conservation support practice factor.

The erosivity factor of rainfall $(\mathrm{R})$ is the product of the kinetic energy of the raindrop and the 30-minute maximum rainfall intensity. In many areas rainfall intensity data are very rare; and attempts have been made to determine erosivity from daily rainfall data (Jain et al., 2001). In Gilgel Gibe-1 catchment, 30-minute rainfall intensity data is not available and the R-factor value is estimated using the regression equation developed by Zelalem Birru, (2006) for Jimma area where the catchment is located. The equation is:

$\mathrm{R}=0.002 \mathrm{P}^{2}-4.89 \mathrm{P}+5996.11$

Where: $\mathrm{R}$ is the rainfall-runoff erosivity factor $(\mathrm{MJ}-\mathrm{mm} /$ ha.h.year) and $\mathrm{P}$ is the mean annual rainfall ( $\mathrm{mm})$. Daily precipitation of 30 year (1985-2015) data for eight stations (four stations in the catchment and four neighboring stations) were taken from National Meteorological Agency and checked for missing, homogeneity, and consistency before using for further analysis. Using this data for each stations R-factor value is calculated and mapped through interpolation using 'Kriging' method in spatial analysis tool in Arc GIS environment.

The soil erodibility factor is based on the soil texture, structure, organic matter, and permeability. The soil 
survey is conducted throughout the catchment and a total of 119 composite soil samples are collected for soil textural class and organic matter analysis by (Walkley black method) and (hydrometer method) respectively. Using the equation below developed by (Foster et al.,1991) soil erodibility factor (K-value) for each soil sample is calculated and soil erodibility map is generated as a raster data through interpolation by 'Kriging' method.

$K=\left[2.1 M^{1.14} \times 10^{-4}(12-a)+3.25(b-2)+2.5(c-3)\right] / 100$

where, $M=$ particle size parameter; (percent silt + percent very fine sand) $(100-$ percent clay), $a=$ percent organic matter, $b=$ soil structure code used in soil classification; (very fine granular $=1$, fine granular $=2$, medium or coarse granular $=3$, blocky, platy or massive $=4$ ) and $c=$ soil permeability class; (rapid=1, moderate to rapid $=2$, moderate $=3$, slow to moderate $=4$, slow $=5$, very slow $=6$ )

The $L$ and $S$ factors represent the effects of slope length $(L)$ and slope steepness $(S)$ on soil erosion. LS-factor is calculated by Unit Stream Power Erosion and Deposition (USPED) method with the equation given by (Jim et al., 2012).

$L S=$ Power ("flow accumulation"*[cell resolution]/22.1, 0.4)*Power(Sin("slope in degree"*0.01745))/0.09, $1.4) * 1.4$.

Cover (C) and management $(\mathrm{P})$ factors are determined from land use land cover map of the catchment by reclassifying with the help of spatial analysis tools in ArcGIS after the generation of land use land cover map from Landsat image. C- factor values assigned for each land use type by different researchers are used, while P-factor values adapted for Ethiopian condition by Nyssen et al. (2009c) are used for this study.

\section{Determination of Sediment Delivery Ratio by SEDD Model}

The sediment delivery ratio for the catchment, SDR, is defined as the fraction of the gross soil loss from the catchment that actually reaches the outlet. SDR was estimated by the equation given by Ferro (1997) as a function of travel time:

$\mathbf{S D R}_{\mathbf{i}}=\exp \left(-\boldsymbol{\beta} . \mathbf{t}_{\mathbf{i}}\right) ; \mathbf{t}_{\mathbf{i}}=\sum_{n=1}^{N} \frac{\lambda \mathbf{n}}{V_{\mathbf{i}}} ; \quad \mathbf{V}_{\mathbf{i}}=\mathbf{d}_{\mathbf{i}} \mathbf{S}^{\mathbf{1} / 2}$

where: $t_{i}$ is the travel time (hr); $\beta$ is a watershed-specific parameter; $\lambda_{\mathrm{n}}=$ length of segment in flow path $n, \mathrm{~m} ; \mathrm{Vi}$ $=$ flow velocity, $\mathrm{m} / \mathrm{s} \mathrm{d}_{\mathrm{n}}=$ surface roughness coefficient for cell $n, \mathrm{~m} / \mathrm{s} ; \mathrm{S}_{\mathrm{n}}=$ slope for cell $n, \mathrm{~m} / \mathrm{m}$. The equation developed by Foster et al., (1977), in Barriosy Quinonez, (2000) was used to develop length of segment, $\lambda_{n}$.

$L=(\lambda / 22.13)^{m} ; \lambda^{m}=L *(22.13)^{m} ; m=(F /(1+F))$

Where; $\mathrm{L}=$ slope length, $\mathrm{F}=$ slope angle.

$F=\left(\left(\sin ^{\prime \prime} \%\right.\right.$ slope\%"*0.01745)/0.0896)/(3*power (sin ("\%slope"*0.01745), 0.8) +0.56))

$L=($ power $((" \%$ flow accu\%" +625),("\%m\%" +1))-power("\%flow accu',("\%m\%" +1))) /(power $(25$, ("\%m\%" $+2)) * \operatorname{power}(22.13, " \% m \% "))$

Slope length $(\lambda n)$, a surface roughness $(\mathrm{dn})$, surface flow velocity (vi) and slope (Sn) was used for travel time calculation by the help of Arc GIS tools at a cell level. The slope of the catchment was first generated from DEM by the help of a spatial analyst tool in GIS. The surface roughness value for each land use, dn, was adapted from the table given by Haan et al, 1994 as cited in Lally, (2013).

The watershed-specific parameter $\beta$ depends primarily on watershed morphological data (Ferro, 1997). Fernandez et al., (2003) estimated $\beta$ with inverse modeling and concluded that it is not sensitive and for more watersheds, $\beta$ is taken as unity. Similarly, for this study also $\beta$ was taken unity for simplicity. Sediment yield of the catchment was calculated as the product of mean annual soil loss obtained from the RUSLE model and sediment delivery ratio obtained from the SEDD model.

SY $=\sum$ Ai. SDRi

Where: Ai is soil loss in pixel $\mathrm{i}$ and SDRi is sediment delivery ratio in pixel $\mathrm{i}$.

The catchment was divided in nine Sub watersheds on the bases of major rivers and tributaries in the catchment. Sub watershed with high mean sediment yield was considered as the major source of the sediment yield and vice versa in this study. Also the Sub watersheds were classified as Slight (5-7 ton ha $^{-1}$ year $\left.{ }^{-1}\right)$, Moderate (7-9

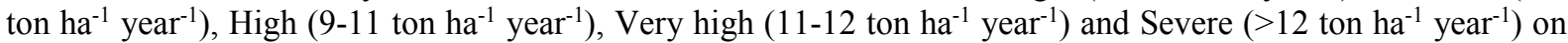
the bases of mean sediment yield. 


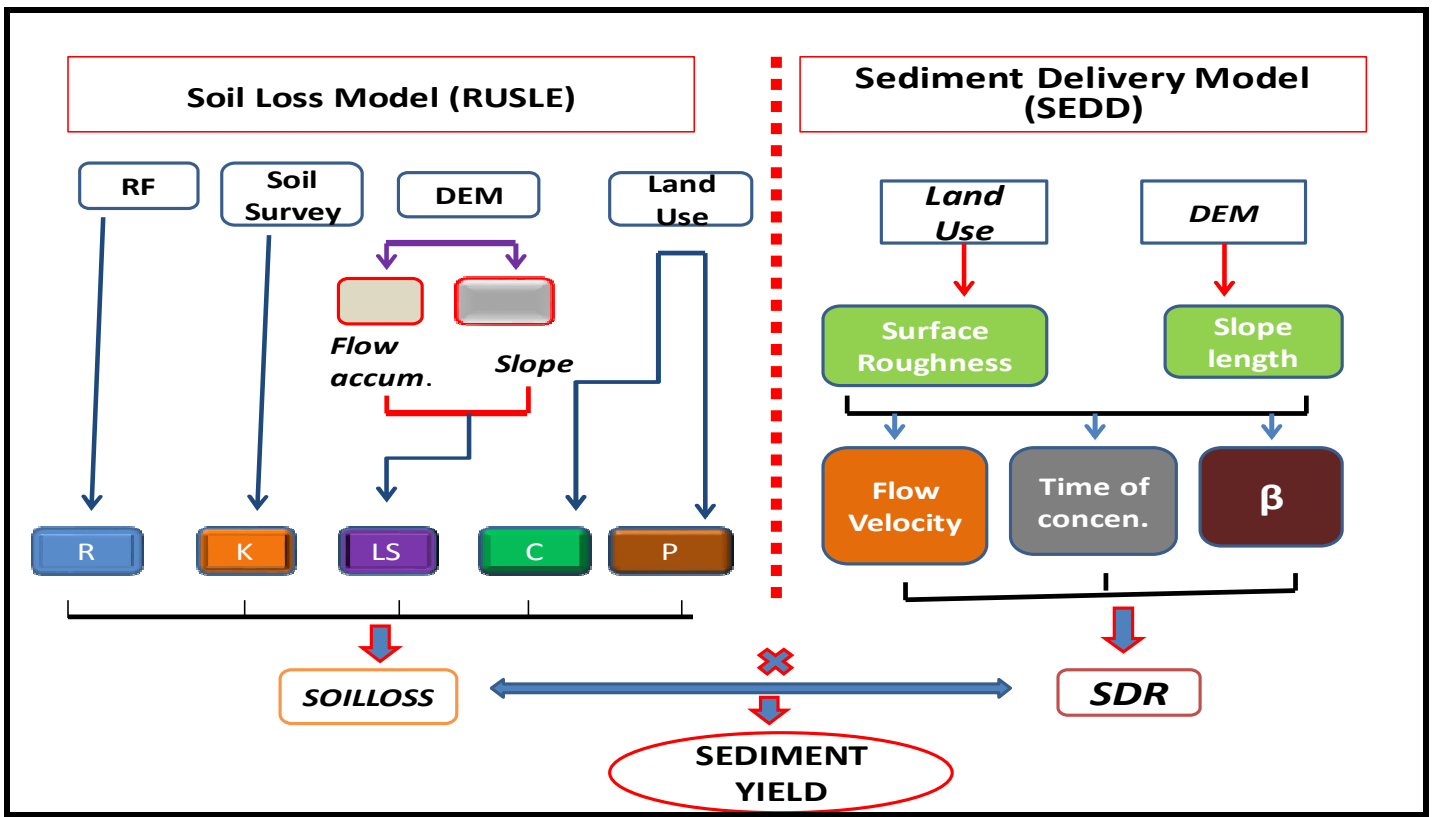

Figure 3. Set up of RUSLE and SEDD models for Sediment yield prediction.

\section{RESULTS AND DISCUSSION}

\subsection{Estimated Revised Universal Soil Loss Equation (RUSLE) Model Parameters}

Figure 4. depicts the five RUSLE factors and land use/land cover types of the Gilgel Gibe catchment. The R-factor is observed that the highest value occurred in the upper part of the catchment and the lowest at the middle and near the dam (Figure 4a). The mean rainfall runoff erosivity, soil erodibility value, and topographic factor value of the catchment were found $3198.97,0.358$ and 1.163 with a standard deviation of 75.00, 0.36 and 5.00, respectively (Figure 4a; Figure 4b; Figure 4c). and use land cover of the catchment is classified into six major land use land cover classes, namely, cultivation land, grazing land, dense forest, open forest, water body and settlement/build up area (Figure 4d). Figure $4 \mathrm{e}$ presents the C-factor map of the catchment which was generated by reclassifying land use land cover types and assigned $\mathrm{C}$ - value for each classes. The mean $\mathrm{C}$-value of the catchment was found 0.11 with a standard deviation of 0.12 . The only support practice in the study area was contour farming, plowing along the contour, and bunds on some areas of cultivation land only after mass mobilization on integrated watershed management since 2013. In addition, there was no in situ conservation practices on cultivation or cropped lands. Accordingly, P-values of 0.27 and 1 were used for cultivation land and other land use types respectively (figure $4 \mathrm{f}$ ). On the bases of the area of land use types, the weighted P-value of the catchment resulted in 0.43 with the standard deviation of 0.28 . 

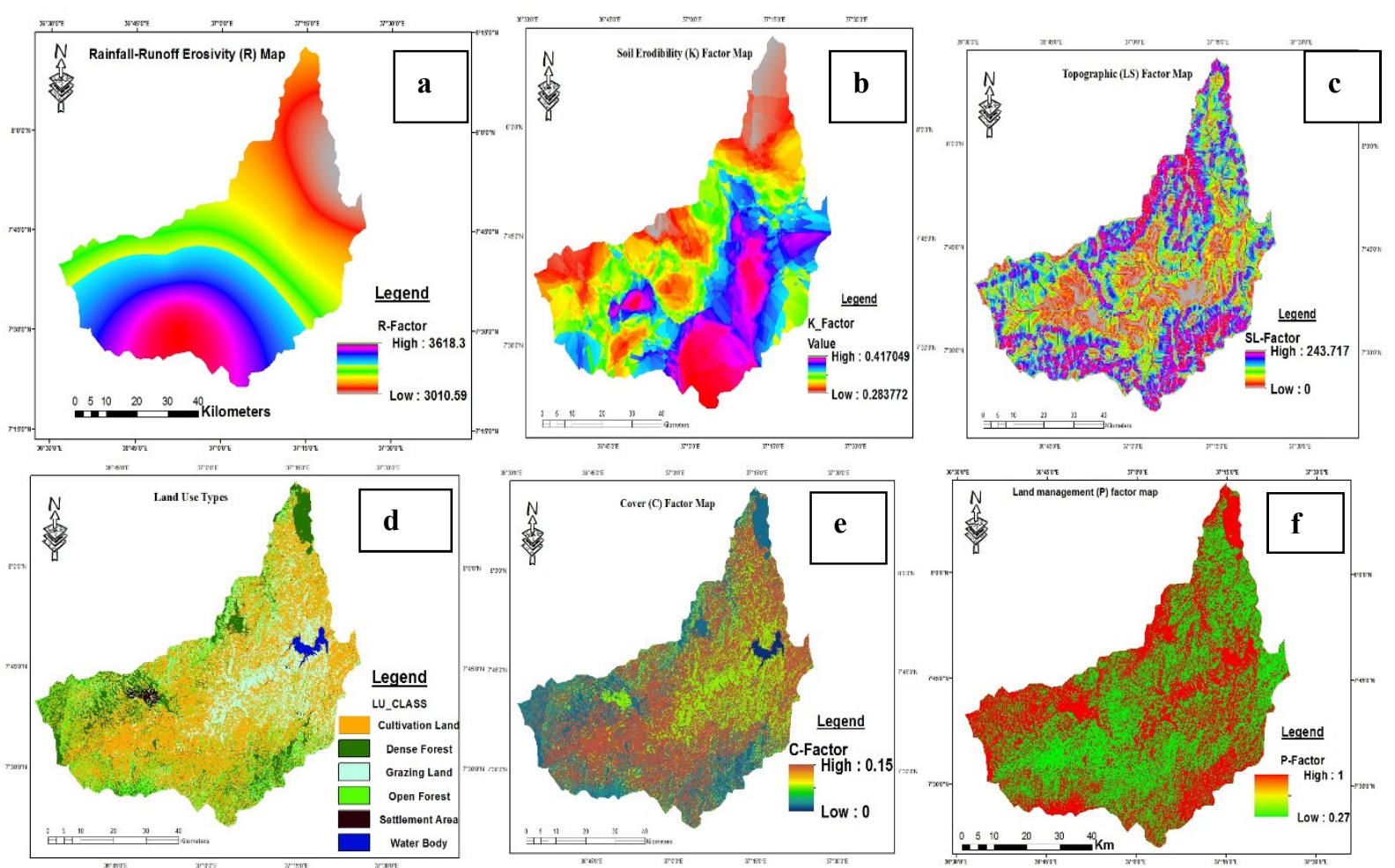

Figure 4. Spatial distribution of rainfall runoff erosivity (R) factor(a), soil erodibility (K) factor (b), topographic (LS) factor (c), land use land cover (d), cover factor (e) and land management (P) factor maps .

\subsection{Estimated Sediment Distribution delivery (SEDD) Model Parameters}

Surface flow velocity is computed as function of slope and surface roughness and it is derived from the values of slope $(\mathrm{m} / \mathrm{m})$ and surface roughness coefficient. Figure 5 depicts the factors maps for surface flow velocity computation and the surface flow velocity map. The slope of the catchment ranges from 0 to 0.72 with a mean slope of $7.3 \%$ (figure 5a). Surface roughness coefficient map was developed by reclassifying land use land cover type map and assign surface roughness values for each land use land cover types. The generated surface roughness shows a maximum surface roughness of 2.21 and minimum of 0 with a weighted mean value of 1.42 (figure $5 \mathrm{~b}$ ). 


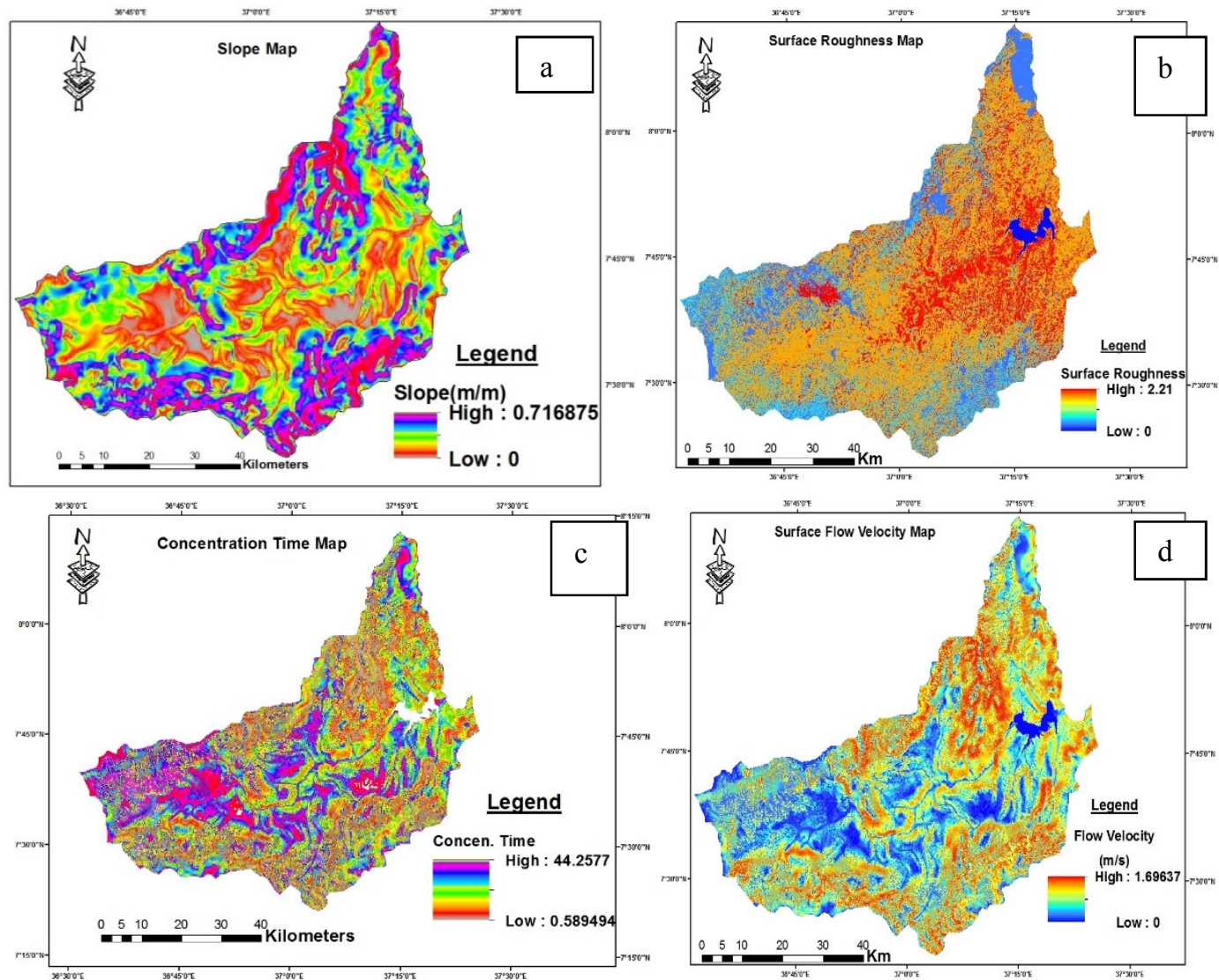

Figure 5. Slope $(\mathrm{m} / \mathrm{m})(\mathrm{a})$, surface roughness (b), surface flow velocity (c), time of concentration (d) and sediment delivery ratio (e) map of the catchment

The mean surface flow velocity of the catchment was found $0.34 \mathrm{~m} \mathrm{sec}^{-1}$ ranging from 0 to $1.69 \mathrm{~m} \mathrm{sec}^{-1}$ with 0.1889 standard deviation (figure 5d). Figure 5e depicts the concentration time map with a mean value of $3.89 \mathrm{hr}$ and ranging from 0.59 to $44.25 \mathrm{hr}$. The spatial distribution of the surface flow velocity indicates that highest value was found on cultivation land and grazing land and lowest on water bodies and forest areas. This is due to soils from cultivation land and grazing land are exposed to erosion and it is susceptible to soil transporting agents. This result implies that areas with good coverage hinders the soil moving with surface runoff by minimizing its velocity and make it deposit at gentle slopes before reaching the reservoir.

As the concentration time map shows areas far from the out let have low values because it takes long time to reach the outlet point; whereas, areas near to the outlet have low time of concentration values. Areas with high concentration time contributes lower amount of sediment yield and vice versa, because as time of concentration increases deposition takes place and the amount of sediment delivered to the reservoir decreases.

\subsection{Estimated Sediment Yield}

Figure 6 depicts the annual soil loss map, the sediment delivery ratio map and the sediment yield map. The mean annual soil loss of the catchment was estimated 62.98 ton $^{-1} \mathrm{year}^{-1}$ with a range of 0 to 10923.80 ton ha ${ }^{-1} \mathrm{year}^{-1}$ (figure 6a). The mean sediment delivery ratio which was derived from time of concentration and catchment/watershed specific parameter was found 0.1367 ranging from 0 to 0.55 (figure $6 \mathrm{~b}$ ). As figure $6 \mathrm{c}$ shows the mean sediment yield of the catchment reaching the outlet is 8.61 ton $\mathrm{ha}^{-1}$ year $^{-1}$ ranging from 0 to 2354.07 ton $\mathrm{ha}^{-1} \mathrm{year}^{-1}$ with a standard deviation of 29.43 ton $\mathrm{ha}^{-1}$ year $^{-1}$. The overall sediment yield from the catchment to the outlet was estimated $3.63 \times 10^{6}$ ton/year. Sediment yield was found high at steeper slope areas of the catchment and low in areas with gentle slopes at bottom valley of the catchment. This is due to surface flow velocity and time of concentration are low, The same is true for forest areas. 


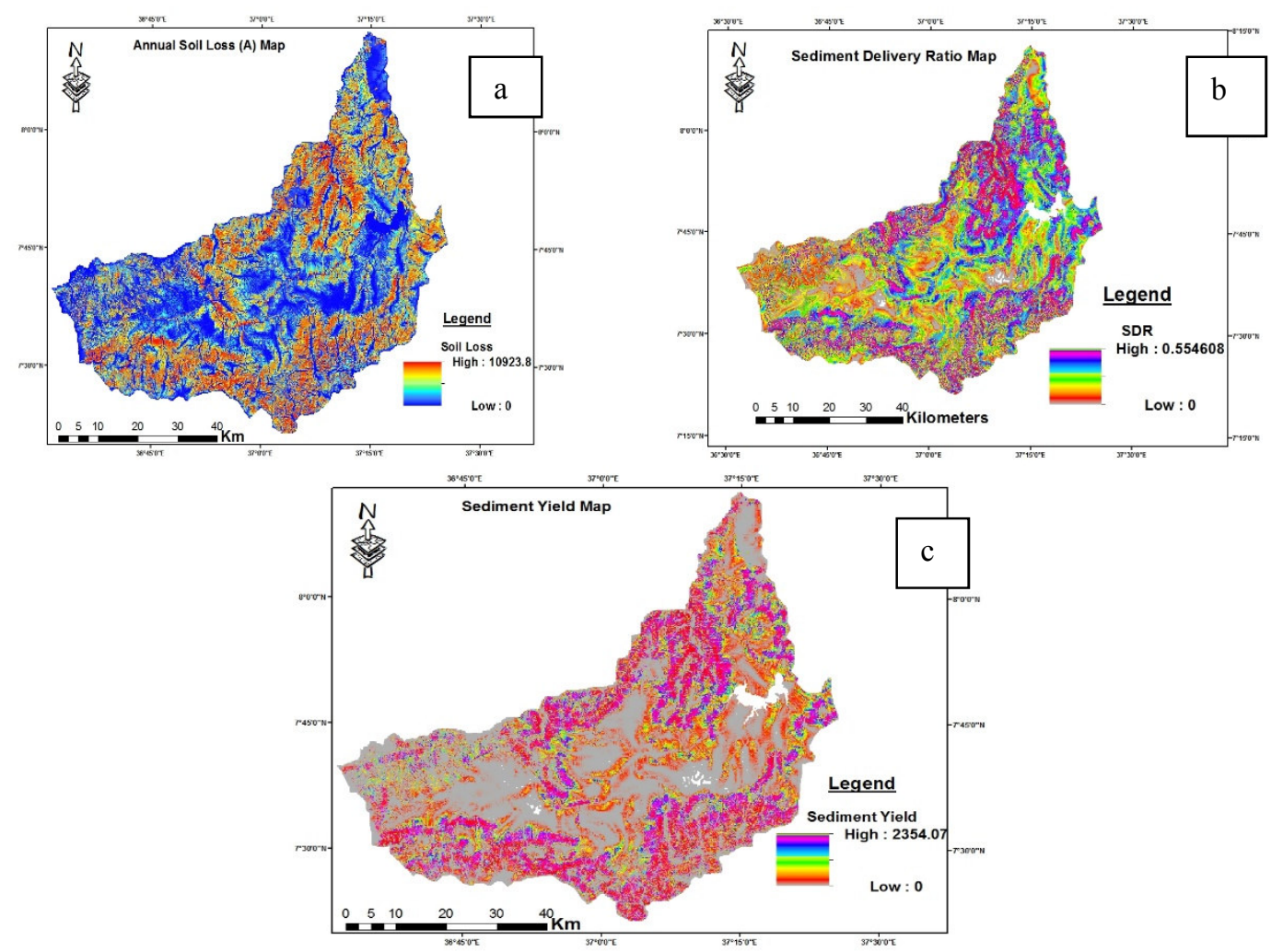

Figure 6. sediment yield map (c) derived from soil loss (a) and sediment delivery ratio map (b)

In Ethiopia, according to various technical reports, designers have used a range of sediment yield values between 8 and 12 ton $\mathrm{ha}^{-1} \mathrm{yr}^{-1}$ (Haregeweyn et al., 2005). The result of this study, which is 8.61 ton ha- $\mathrm{yr}^{-1}$, is fallen in this range. Sediment deposition rate reaches $9 \cdot 2$ ton $\mathrm{ha}^{-1}$ year $^{-1}$ in the north part of Ethiopia (Nyssen et al., 2007) and 30 ton ha $^{-1}$ year-1 $^{-1}$ in south-western Ethiopia (Hurni, 1985). The research conducted in Gilgel Gibe-1 catchment using SWAT model by Adugna et al., (2013) resulted sediment yield ranging from negligible value to 39 ton $\mathrm{ha}^{-1}$ year-1. Their study reported that at the inlet point to the reservoir the annual sediment load to the reservoir was about $122.73 \times 10^{3}$ ton year ${ }^{-1}$. Devi.et al., (2008) reported the total sediment load from Gilgel Gibe-1 catchment at the dam site was $45 \times 10^{6}$ ton/year, which is about 106.68 ton $^{-1} \mathrm{y}^{-1} \mathrm{year}^{-1}$.

Negash and Mesfin, (2011) reported sediment yield of Gilgel Gibe-1 catchment varies ranging from 0.43 to 132.08 tonha $^{-1}$ year $^{-1}$ due to variation in the catchment characteristics. However, Tufa (2016) conducted a research using SWAT on Gilgel Gibe-1 catchment and came out with the result of average annual sediment yield of 106.178 ton $\mathrm{km}^{-2}$ year ${ }^{-1}$ which is equivalent to 1.1 tonha $^{-1}$ year $^{-1}$.

\subsection{Identified Sediment Source Through Prioritization of Sub-Watersheds}

Table 1 shows sediment yield classes, severity classes and their areal coverage. Accordingly, slight sediment yield class covers large area which is $78.22 \%$ followed by medium sediment yield class which is about $6 \%$. About $7.83 \%$ of the catchment was found under very high and severe sediment yield classes, whereas about $2.16 \%$ of catchment is under very severe sediment yield severity class.

Table 1. Severity class and area coverage based on sediment yield (tons ha ${ }^{-1} \mathrm{year}^{-1}$ ).

\begin{tabular}{|c|c|c|c|}
\hline $\begin{array}{l}\text { Sediment yield class } \\
\left(\mathrm{t} \mathrm{ha}^{-1} \text { yesr }^{-1}\right)\end{array}$ & Severity class & Area coverage $\left(\mathrm{km}^{2}\right)$ & $\begin{array}{c}\text { Percentage of area } \\
\text { coverage }\end{array}$ \\
\hline 0 to 5 & Slight & 3299.35 & $78.22 \%$ \\
\hline 5 to 10 & Medium & 253.82 & $6.02 \%$ \\
\hline 10 to 20 & High & 243.09 & $5.76 \%$ \\
\hline 20 to 40 & Very high & 198.35 & $4.70 \%$ \\
\hline 40 to 80 & Severe & 132.18 & $3.13 \%$ \\
\hline$>80$ & Very severe & 91.21 & $2.16 \%$ \\
\hline
\end{tabular}

The Sub watersheds are prioritized based on mean sediment in the order of SW4, SW5, SW3, SW6, SW7, SW8, SW9, SW2 and SW1 as shown in Table 2. 
Table 2. Priority of sub-watersheds based on mean annual sediment yield (tons ha $^{-1}$ year $^{-1}$ ).

\begin{tabular}{|c|c|c|c|c|}
\hline \multirow{2}{*}{ Sub -Watersheds } & \multicolumn{2}{|c|}{ Area } & \multirow{2}{*}{$\begin{array}{c}\text { Sediment yield } \\
\text { (ton ha-1yr-1) }\end{array}$} & Priority by mean Sediment yield \\
\cline { 2 - 3 } & $\left(\mathrm{KM}^{2}\right)$ & $(\%)$ & 5.57 & 9 \\
\hline SW1 & 579 & 13.73 & 6.49 & 8 \\
\hline SW2 & 555 & 13.16 & 9.52 & 3 \\
\hline SW3 & 328 & 7.78 & 12.75 & 1 \\
\hline SW4 & 308 & 7.3 & 11.1 & 2 \\
\hline SW5 & 693 & 16.43 & 9.28 & 4 \\
\hline SW6 & 578 & 13.7 & 8.59 & 6 \\
\hline SW7 & 382 & 9.06 & 8.41 & 7 \\
\hline SW8 & 541 & 12.83 & 7.07 & \\
\hline SW9 & 254 & 6.02 & 8.61 & 5 \\
\hline \multicolumn{2}{|l}{ Weighted Mean } &
\end{tabular}

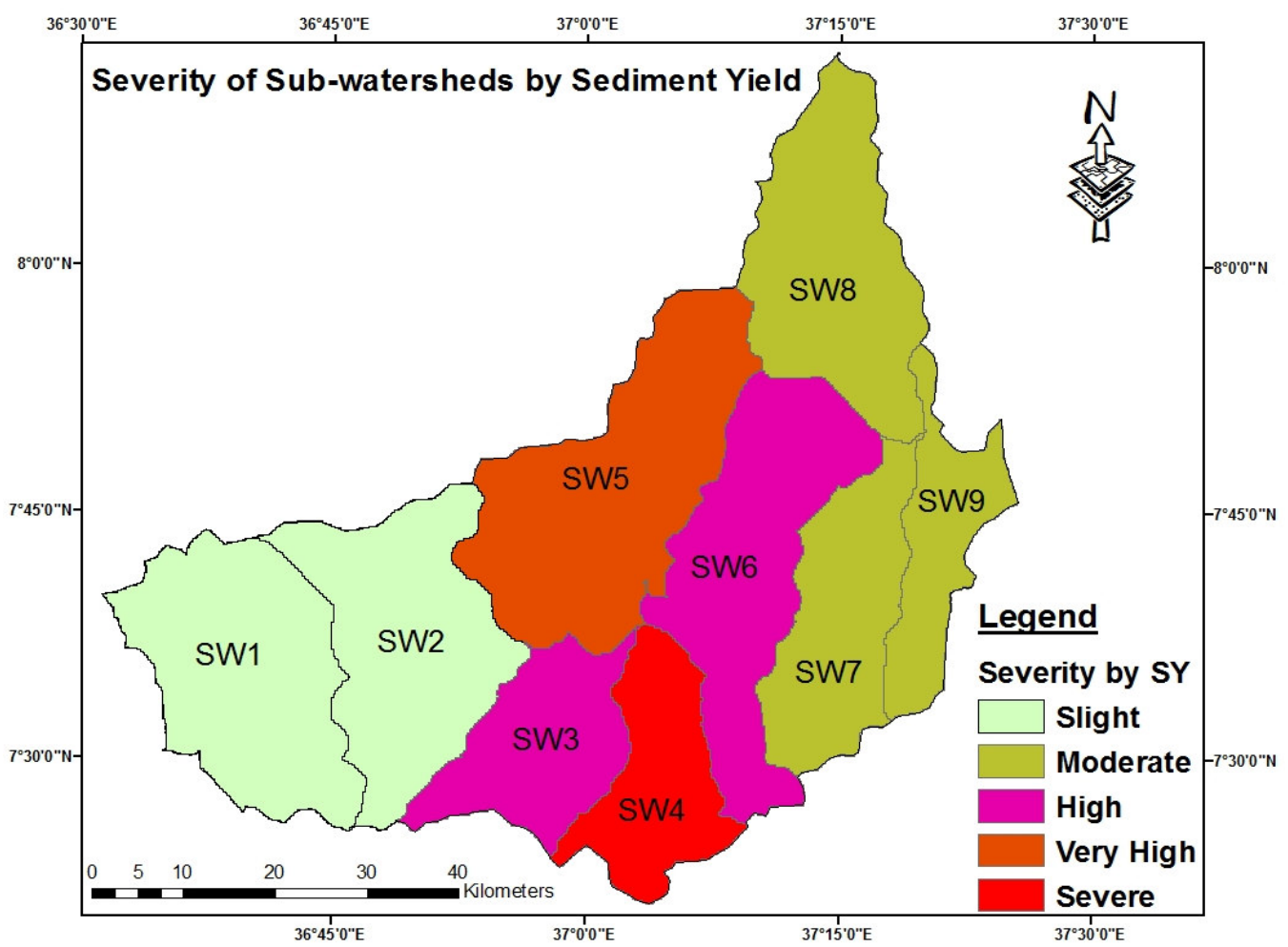

Figure 7. Severity class of sub watersheds based on mean annual sediment yield

Figure 7 reveals the severity class of sub watersheds based on the mean annual sediment yields. In this regard, SW3 and SW6 are under high severity class. SW4 and SW5 are categorized under severe and very high severity classes, respectively. Further, SW7, SW8 and SW9 are fallen under moderate class whereas SW1 and SW2 are under slight soil loss severity class. Generally, SW4, SW5 and SW3 are found the major source of sediment yield to the reservoir with a rank of 1 to 3 . These sub watersheds are found in the middle part of the catchment with steep slopes. In these sub watershed, cultivation of annual crops, mainly maize, are the common farming practices.

\section{CONCLUSION AND RECOMMENDATIONS}

The RUSLE model parameters: rainfall-runoff erosivity, soil erodibility, topographic factor, cover factor and land management factor are found with a weighted mean value of $3198.97 \mathrm{MJmmha}^{-1} \mathrm{~h}^{-1} \mathrm{year}^{-1}, 0.358$ ton ha h ha-1 $\mathrm{MJ}^{-}$ ${ }^{1} \mathrm{~mm}^{-1}, 1.163,0.11$ and 0.43 , respectively. The mean soil loss of Gilgel Gibe-1 catchment is estimated 62.98 ton $\mathrm{ha}^{-1}$ year $^{-1}$ which is $26.56 \times 10^{6}$ ton year ${ }^{-1}$. In addition, mean weighted sediment delivery ratio (SDR) is found 0.1367 for the catchment at the dam site from SEDD model. The sediment yield of the catchment is estimated 8.61 ton $\mathrm{ha}^{-1}$ year $^{-1}$. From the whole catchment areas about $3.63 \times 10^{6}$ ton year-1 sediment reached the reservoir

Sediment yield is found high on areas having high sediment delivery ration which could be affected by surface roughness of the area, surface flow velocity of running water, time of concentration to the out let and specific catchment characteristics. High surface roughness and high time of concentration result less sediment yield by resulting less sediment delivery ratio; while high surface flow velocity, less roughness and less time of 
concentration results high sediment delivery ratio which in turn resulted in high sediment yield.

Accordingly, Sediment yield with slight severity class $\left(0-5\right.$ ton ha $^{-1}$ year $\left.^{-1}\right)$ covers large areas $(78.22 \%)$ of the catchment followed by medium severity class $\left(5-10\right.$ ton ha $^{-1}$ year $\left.^{-1}\right)$ which is $6.02 \%$. About $13 \%$ of the catchment area is fallen under high (10-20 ton ha- year $\left.^{-1}\right)$, very high $\quad\left(20-40\right.$ ton ha ${ }^{-1}$ year $\left.^{-1}\right)$ and severe $\left(40-80\right.$ ton $^{-1}$ year $\left.^{-1}\right)$ severity classes. $2.16 \%$ of the catchment areas is under very severe severity class $\left(>80\right.$ ton ha $^{-1}$ year-1 $\left.^{-1}\right)$.

On the bases of mean annual sediment yields, sub watershed SW4, SW5, SW3, SW6, SW7, SW8, SW9, SW2 and SW1 are prioritized in the order of 1 to 9, respectively. Sub watersheds with first priority implies that watershed highly contributes more sediment yield to the reservoir at the outlet, while sub watersheds with the least priority contributes less sediment yield to the reservoir.

According to the identified 'hotshot' areas ,sub-watershed priorities, appropriate soil and water conservation structures with appropriate design should be implemented to minimize the amount siltation delivered to Gilgel Gibe-1 reservoir. Buffer zone should be delineated around the reservoir to avoid cultivation and grazing practices adjacent to the reservoir. In addition, steeper slope areas that are being under cultivation for annual crops should be changed to area closure and at least to perennial crops like coffee. The effect of soil erosion or sedimentation is not sector or organization specific, rather it is holistic. Because of this recommended structures should be implemented through multi disciplinary and integrated approach, specially through integrated watershed management approach.

\section{REFERENCE}

Adeba G, 2016. Estimation of soil loss using Revised Universal Soil Loss Equation and determinants of soil loss in Tiro Afeta and Dedo districts of Jimma zone, Oromia Regional State, Ethiopia. Trends Agric. Econ., 9: 112.

Adugna T., Saathoff F., Seleshi Y., Gebissa A.,2013. Evaluating the Effectiveness of Best Management Practices in Gilgel Gibe Basin Watershed-Ethiopia. J. Civil Eng. Archite.7 (10): 1240-1252.

Bezuayehu T., 2006. People and dams: environmental and socio-economic changes induced by a reservoir in Fincha'a watershed, western Ethiopia. Tropical Resource Management Papers 75. Wageningen University, Wageningen, the Netherlands.

Broothaerts T., Kissi E., Poesen J., Van Rompaey A., Getahun K., Van Ranst E., Diels J. 2012. Spatial patterns, causes and consequences of landslides in the Gilgel Gibe catchment, SW Ethiopia. Catena 97 (2012) 127136

Dawud H., Firezer A. , Mahmud M., Mohammed I. and Seid E., 2014. Application of GIS for Modeling Soil Loss Rate in Gilgel Gibe Sub-Catchment Using Universal Soil Loss Equation (USLE). Jimma University Institute of Technology Department of Water Resources and Environmental Engineering

Demissie, Saathoff F., Sileshi Y., Gebissa A., 2013. Climate change impacts on the streamflow and simulated sediment flux to Gilgel Gibe 1 hydropower reservoir Ethiopia. European International Journal of Science and Technology Vol. 2 No. 2

Devi R., Subalewu T., Worku L., Bishaw L., Abebe B., 2008. Assessment of siltation and nutrient enrichment of Gilgel Gibe dam, Southwest Ethiopia, Bio. Resource Technology 99 975-979.

FAO-UNESCO, 1974. FAO/UNESCO Soil Map of the World 1:5.000.000, UNESCO, Paris. Fubelli, G., Abebe, B., Dramis, F., Vinci, S., 2008. Geo-morphological evolution and present-day processes in the Dessie Graben (Wollo, Ethiopia). Catena 75, 28-37.

Fernandez C., Wu J.Q., McCool D.K., Sto“ckle C.O., 2003. Estimating water erosion and sediment yield with GIS, RUSLE, and SEDD. J. Soil Water Conserv. 58, 128-136.

Ferro V., 1997. Further remarks on a distributed approach sediment delivery. Hydrol. Sci. J. 42, 633-647.

Ferro V., and Porto P., 2000. Sediment delivery distributed (SEDD) model. J. Hydrol. Eng., 10.1061/(ASCE)10840699(2000)5:4(411), 411-422.

Foster G. R.,. Yoder D. C., Weesies G. A., McCool D. K., McGregor K. C., and Bingner R. L. 2002. User's guide-Revised Universal Soil Loss Equation Version 2 (RUSLE 2). USDA-Agricultural Research Service, Washington, DC.

Foster G.R. and Meyer L.D., 1972. A closed-form soil erosion equation for upland areas. In Shen, H.W. (ed.), Sedimentation. Department of Civil Engineering, Colorado State University, Fort Collins: 12.1-12.19. Foster, R.L. and Martin, G.L. 1969. Effect of unit weight

Foster GR, McCool DK, Renard KG. and Moldenhauer WC., 1991. Conversion of the universal soil loss equation to SI Metric Units. J Soil Water Conservation. 36:355-359

Haan C.T, Barfield B.J, Hayes J.C.1994. Design hydrology and sedimentology for small catchments. Academic, New York.

Haregeweyn N., Poesen J., Nyssen, Verstraeten G., de Vente J., Govers, G., Deckers S., Moeyersons, J. ,2005. Specific sediment yield in Tigray-Northern Ethiopia: Assessment and semi-quantitative modeling. Geomorphology 69 (1-4): 315-331. 
Hathaway T., 2008. What Cost Ethiopia's Dam Boom? A look inside the Expansion of Ethiopia's Energy Sector. $26 \mathrm{pp}$.

Hurni H., 1985. Erosion-productivity-conservation systems in Ethiopia. In: Proceedings of paper presented at the 4th international conference on soil conservation, Maracay, Venezuela

Jain S.K., Kumar S. and Varghese J., 2001. Estimation of soil erosion for a Himalayan watershed using GIS technique. Kluwer Academic Publishers. Water Resources Management 15, pp.41-54

Jim Pelton, Eli Frazier, and Erin Pickilingis, 2012. Calculating Slope Length Factor (LS) in the Revised Universal Soil Loss Equation (RUSLE)

Kidane D., and Alemu B.,2015. The Effect of Upstream Land Use Practices on Soil Erosion and Sedimentation in the Upper Blue Nile Basin, Ethiopia. Review. Research Journal of Agriculture and Environmental Management. Vol. 4(2), pp. 055-068.Available online at http://www.apexjournal.org.

Lally L. B., 2013. Applying the RUSLE and SEDD Equations to an Agricultural Watershed in Southwest Virginia: A Case Study in Sediment Yield Estimation Using GIS. Thesis submitted to the faculty of the Virginia Polytechnic Institute and State University in partial fulfillment of the requirements for the degree of Master of Science In Civil Engineering.

Mati B. M., and Veihe A., 2001. Application of the USLE in a savannah environment: Comparative experiences from East and West Africa. Singapore Journal of Tropical Geography 22:138-155.

Musa A.S., El-Zein S.M., El-sayed M., Mirghani M. and Golla S. 2005. Assessment of the current status of the nile basin reservoir sedimentation problems. Nile Basin capacity Building Network-for River Engineering.

Nebiyu A., 2010. The Sustainable use of Soil Resources of Gilgel Gibe dam catchment. Proceeding of the national workshop in integrated watershed Management on Gibe-Omo basin, Jimma University and Gilgel Gibe site, $39-42$.

Negash T. and Mesfin K., 2011. Proceeding of the national workshop in integrated watershed management on gibe - omo basin, PHE Ethiopia Consortium 2011.

Niu D., Wang H and Lai L., 2003. Soil Erosion and Conservation; http://159.226.205.16/ curriculum/3w/ 01/cause/index.html; visited on November 12, 2009.

Nyssen J., Poesen J., Gebremichael J., Vancampenhout D., D’aes K., Yihdego M., Govers G., Leirs G., Moeyersons H., Jozef Naudts J., Haregeweyn N., Haile M., Deckers J., 2007. Interdisciplinary on-site evaluation of stone bunds to control soil erosion on cropland in Northern Ethiopia. Soil. Till. Res. 94: 151163.

Nyssen J., Poesen J., Haile M., Moeyersons J., Deckers J., Hurni H.,2009. Effects of land use and land cover on sheet and rill erosion rates in the Tigray highlands, Ethiopia. Zeitschrift für Geomorphologie 53:171-197

Prasannakumar V., Vijith H., Geetha N. and Shiny R., 2011. Regional Scale Erosion Assessment of a Sub-Tropical High land Segment in the Western Ghats of Kerala, South India, Water Resources Management, Vol. 25 , No. 14, pp. 3715-3727 http://dx.doi.org/10.1007/s11269-011-9878-y.

Renard K.G., Foster G., Weesies G., McDool D., and Yoder D., 1997. Predicting Soil Erosion by Water: A Guide to Conservation Planning with the Revised Universal Soil Loss Equation (RUSLE). Agricultural Handbook 703, USDA-ARS.

Tadesse S., Milesi J.P., Deschamps Y., 2003. Geology and mineral potential of Ethiopia: a note on geology and mineral map of Ethiopia. Journal of African Earth Sciences 36.

Tufa F., 2016. Sediment Management in Reservoir, Case study of Gilgel Gibe-I Dam,A thesis submitted and presented to the School of Graduate Studies of Addis Ababa University in Partial fulfillment of the Degree of Masters of Science in Civil Engineering Under Hydraulics Engineering. Ethiopia, Addis Abeba.

Zelalem B., 2006. Estimation of Rainfall Erosion Potential and Development of Iso-Erodent Map of Oromia Regional state Based on Daily Rainfall Amount. An Msc Thesis Presented to the school of Graduate Studies of Haramaya University. 62p 